\title{
教育講演
}

\section{9. ニューロパチーの臨床}

祖父江 元

Key words : Charcot-Marie-Tooth病, 家族性アミロイドポリニューロパチー, Guillain-Barré症候群, 慢性 炎症性脱䯣性多発神経炎

はじめに

ニューロパチーは近年, 病態の解明や有効な 治療法の確立に大きな進展がみられ，その診療 体系が大きく変わりつつある.特に, 遺伝性ニュー ロパチーの病因・病態解明と炎症性ニューロパ チーの治療法の開発に進歩が著しい。遺伝性 ニューロパチーの中でも, シャルコー・マリー・ トゥース病 (Charcot-Marie-Tooth病：以下 $\mathrm{CMT}$ )と家族性アミロイドポリニューロパチー (familial amyloidotic polyneuropathy: 以下 FAP）は遺伝子診断の普及によって, 従来考え られていたよりも頻度の高いニューロパチーと して認識されつつある. また，クローニング技 術の進歩とゲノムプロジェクトによって，一部 については原因遺伝子が同定され，遺伝子診断 が可能になっており，それと共に，高齢発症例， 孤発例や非定型例など, 従来の教科書的な臨床 特徴にとどまらず，広いスペクトラムをもった 疾患であることも明らかになってきている。一 方, 炎症性ニューロパチーでは, 特にギラン・ バレー症候群（Guillain-Barré：以下GBS）と慢 性炎症性脱髄性ポリニューロパチー (chronic inflammatory demyelinating polyneuropathy : 以

\footnotetext{
そぶえげん：名古屋大学神経内科
}

下CIDP) などの自己免疫性ニューロパチーはい まや治療可能な代表的神経疾患となっている. 特にGBSでは欧米を中心に大規模な無作為対照臨 床試験 (randomized controlled trial:RCT)が次々 と行われ、ニューロパチーにおける evidence based medicineの先駆けとなった。本講演では CMT, FAP, GBS, CIDPを中心に, 臨床像の理 解とともに我が国の臨木疫学的特徴, さらに最 近の治療法について述べる.

\section{1. 遺伝性ニューロパチー}

\section{1) $\mathrm{CMT}$}

CMTは逆シャンパン型の下腿筋葁縮を伴う遺 伝性ニューロパチーとしてつとに知られた疾患 であるが，遺伝子診断の進歩とともに多様な臨 床所見が明らかになってきている．近年，CMT に执いて末梢神経髄鞘を構成する蛋白peripheral myelin protein22(PMP22), myelin protein zero (MPZ) と gap junction蛋白である connexin 32 (Cx32)の各遺伝子の変異 (重複, 欠失, 点変異 など）が証明され，遺伝子異常の立場からの分 類が行われるようになり，従来のDyck分類の病 型との対応関係が明らかになってきているが， phenotype-genotype解析はまだ進行中である。 CMTの有病率は欧米では人口 10 万人に 40 人, わが国では人口 10 万人に 1.5 4 人程度と推測さ 
れている。

(1) CMT 1 型

CMTの中では最も多く占め $(70 \sim 80 \%)$ ，その 中核をなす。下肢遠位の筋力低下で発症し，運 動神経・感覚神経を主体に障害され, 緩徐進行 性の経過を示す. 大腿の下 3 分の 1 から下腿に かけての筋萎縮 (逆シャンペンボトル型の足) と 足の変形（凹足）が特徴的である.末梢神経伝 導速度は高度に低下し，しかも末梢神経の種類 や部位によらず一様に低下する。この伝䑟速度 の低下は症状が進展してもほほ一定であるが, 振幅は低下する.この電気生理学的所見は臨床 症状より鋭敏とされ，無症候の家族などにおい ても末梢神経伝導速度の延長がみられる，遺伝 子異常に基づいて, A型, B型, C型，D型に主に 分類される. $\mathrm{A}$ 型と $\mathrm{B}$ 型で殆どを占めており, 比 率はCMT 1A 90\%,CMT 1B 10\%とされる.CMT $1 \mathrm{~A}$ では第 17 染色体 17p11.2-12 のPMP22 遺伝子 を含む約 $1.5 \mathrm{Mb}$ 領域のtandemな重複が証明され る. 少数であるがPMP22 遺伝子の点変異による CMT1Aも存在する.CMT1Bでは末梢神経の髄 鞘の主成分である第 1 染色体 $1 \mathrm{q} 22-23$ 上のMPZ 蛋白の遺伝子の点変異によるアミノ酸置換や欠 失がみられる、腓腹神経病理でtomaculaが多く みられるのが特徴である.MPZ遺伝子の点変異 には軸索型の存在が明らかになっており，難聴 やAdie瞳孔などの随伴症状がある.CMT1D型は early growth response2（EGR2）の点変異によ る. CMT1C型の遺伝子座は第 16 染色体上にあ ることがわかっている.

\section{(2) CMTX型}

CMTXはX染色体Xq13.1のconnexin 32(Cx32) 遗伝子の点変異によるアミノ酸置換やフレーム シフト変異などがみられる.Cx32 蛋白はP0蛋白 やPMP-22蛋白がcompact myelinに存在するのと 異なり，ランビエ絞輪部に局在する。これ以外 にも Xp22.2，Xq26-28 領域の遺伝子異常によるも のが存在するため, $\mathrm{Cx} 32$ 遺伝子点変異によるも のをCMTX 1 型と呼び, Xp22.2 はCMTX 2 型,
Xq26-28 はCMTX 3 型と呼ばれる. CMTX型で は原因遺伝子がX染色体上に存在するため, 父か ら息子への遗伝がないこと, 女性発症者は男性 発症者に比べ症状が軽いことが特徴である. 神 経学的所見はCMT 1 型に類似している. 運動神 経伝導速度は軽度一中等度低下がみられるが, 通常, 運動神経伝導速度は 30〜 $40 \mathrm{~m} / \mathrm{seckとど}$ まる．腓腹神経病理では軸索再生像が高度にみ られ, onion bulbの形成が軽度みとめられ, 脱䯣 病変と軸索障害が混在する。

\section{(3) CMT 2 型}

CMT 1 型とは对照的に軸索障害型で, 運動神 経伝導速度はほほ正常かわずかに低下するにと どまる一方，筋活動電位は低下する．臨床症状 としては下肢遠位部の筋萎縮, 脱力が 10 歳代前 半までに発症し, 足の変形がみられるなどCMT 1 型ときわめて類似する. 難聴, 視神経萎縮, 知 能低下, 痤性などの随伴症状がしばしばみられ, 単一の疾患単位ではないと考えられる．腓腹神 経病理では軸索再生像が極めて高度にみられ, onion bulbはなく, 有䯣線維密度は軸索再生線維 のため正常かあるいはむしろ平均より多くなっ ていることもある。

遺伝子解析によりCMT2A，2B，2C，2D，2 $\mathrm{E}, 2 \mathrm{P}$ 分類されており, CMT2Aは軸索輸送関 連蛋白であるKIF1B $\beta$ 遺伝子の点変異であること が明らかになった. CMT2EはNEFL遺伝子の点 変異であることが明らかになっている，CMT2 Pは沖縄地方に多発するCMT，CMT2Cは横隔膜 筋麻痺，声帯麻瘦による嗄声を特徽とする。

\section{（4）CMT 3 型（Dejerine-Sottas病）}

常染色体劣性遺伝の肥厚性ニューロパチーと 考えられていた型で，いわゆるDegerine Sottas 病といわれるものである，肥厚型のほか先天性 ミエリン低形成あるいは無形成のものも含まれ, CMT 2 型同様heterogeniousである. Degerine Sottas病においては, PMP22 遺伝子やP0 遺伝子 の変異がみつかっており, CMT 1 型の重症型と もいえる. 
臨床的には乳幼肾期に発症で, 処女歩行が遅 れ, 殆どが 10 歳までに車椅子となる. 外眼筋麻 疩, 対光反射の消失がしばしばみられる.CMT 1 型より高度の脱髄型のニューロパチーを示し, onion bulbの形成は高度で, 末梢神経の肥厚も著 しい. 笳萎縮は下肢優位にみられるが, CMT 1 型より高度で下肢近位部や上肢にも及ぶ. 進行 するといわゆる“こうのとり型の下肢”とよば れる高度の筋萎維がみられる. 深部反射は消失 し, 感覚障害もCMT 1 型より強く, 早期に歩行 困難になる.運動神経伝導速度の低下は高度で, $10 \mathrm{~m} / \mathrm{s}$ 以下になることも少なくない. 䯣液蛋白は 上昇し， $100 \mathrm{mg} / \mathrm{dl}$ 以上に及ぶことが多い.

(5) CMT 4 型

病型ではA，B，C，F型がある。CMT4Aは GDAP遺伝子の点変異によるもので, 嗄声, 声带 麻瘦, 顔面神経麻㽻を呈する. リン酸基の授受 に関与するフォスファターゼMTMR2 や核と細 胞質間の相互輸送に関わるNDRG1 が脱䯣型 ニューロパチーを惹起することが明かになって おり，MTMR2 がCMT4Bの原因遺伝子として同 定されている。CMT4Bでは病理上, tomacula あるいはglobuleが極めて高頻度でみられるのが 特徴である.CMT4Fは艏鞘蛋白periaxinの点変 異によってみられ，こららの䯣鞘蛋白の転写に 関わるEGR2 PSOX10 の遺伝子変異が報告され ている.CMT4Cの遺伝子座は第 5 染色体上にあ ることが明かになった。

(6) その他の新しいCMT

上記のCMT分類には当てはまらない, 新しい 遺伝位異常に基づくニューロパチーも見いださ れている.ヨーロッパのジプシーにみらるCMT はHMSN-Lomと呼ばれ, 感音性難聴を伴い, 瞳 孔異常がみられることもある. 電気生理学的に は脱䯣性変化を示し, 腓腹神経病理ではonion bulb, ミエリンの低形成, axonal loss, Schwann 細胞内の沈着物がみられ, axon-gliaのinteraction の障害と考えられていたが, N-myc downstreamregulated gene 1 遺伝子異常であることがわかっ
てきた. 本邦で性分化異常を伴うCMTが見いだ された。腓腹神経病理では多数の小神経束がみ られ, 神経発生の体節パターンを調節するDHH の遺伝子変異によるものであることがわかった。

\section{2) FAP}

FAPはI型〜IV型に分類され，原因蛋白は transthyretin (TTR)，アポリポ蛋白 (apolipoprotein) AI, gelsolinなどがある. FAP I型（ポ ルトガル型）とFAP П型（インディアナ型）は TTR，FAP Ш型（アイオワ型）はアポリポ蛋白 AI, FAP IV型 (フィンランド型) はgelsolin の変異がみられる。FAP I型はポルトガル，ス ウェーデン, 日本（長野県，熊本県）に大家系 があり，世界で最も症例数が多い。中でも 30 番目のバリンがメチオニンに置換した型（TTR Met30)が最も多く，臨床病理学的に詳しく研究 が行われている.FAP I型は下肢の異常感覚を初 発とし, 高度の自律神経障害を主体とする予後 不良のニューロパチーである。感覚障害は発症 初期に温痛覚障害主体で, いわゆる解離性感覚 障害を呈する。また初期から自発痛がみられる のが特徴である，自律神経障害では頑固な下痢 と便秘の繰り返しや腹痛などの消化器症状のほ か，心伝導障害による不整脈や起立性低血圧な どの循環器症状，陰萎・尿失禁などの症状がみ られる。腓腹神経病理では小径線維・無殖線維 の脱落が優位 (small fiber neuropathy)である. 近年，集積地の家系と関連のない家系が報告さ れ，特に高齢発症例が全国的にみられることが 知られるようになった。高齢発症FAPは男性優 位で，自律神経症候が軽度であるのが特徴的で あり, 病理学的には心筋でのアミロイド沈着が 強く，無䯣神経密度の脱落は軽度である．親子 間の発症年齡差（anticipation）は高齢発症FAP ではみられない。

変異TTRの $90 \%$ が肝缄で産生されているため, この変異TTRの除去を目的として,1990年から 肝移植が行われるようになった。肝移植により 下痢などの消化器症状や起立性低血圧が有意に 
改善するほか, FAPにおいてしばしば問題とな る異常感覚の改善も期待できる。日本において は部分生体肝移植が行われており，手術成績は 良好である。また，FAP患者からの摘出肝をさ らにドナー肝として重症肝疾患患者に再移植す るドミノ肝移植が行われ，有効性が確認されて いる、しかし，肝移植後においても心へのアミ ロイド沈着や眼症状は改善しないことがわかっ ており，新たな治療法の開発が望まれる。

\section{2. 炎症性自己免疫性ニューロパチー}

\section{1) GBS}

GBSはその発症様式, 臨床症候, 脳脊髄液所見 ならびに経過に特徵を有する末梢神経疾患であ る. 病理学的には炎症所見を伴う脱㵦が主体で あり，急性炎症性脱髄性多発ニューロパチー (acute inflammatory demyelinating polyneuropathy: AIDP) とほほ同義語であると考えられて きた.しかし, 近年, 電気生理学的ならびに組 織学的検討により, 従来のAIDPとは異なり一次 的に末梢神経の軸索か障害される軸索障害型GBS の存在が知られるようになった. 現在, GBSは脱 䯣型GBSと軸索障害型GBSの両者を含む。なお， 軸索障害型GBSはCampylobacter jejuni感染の関連 が強く示唆されている.

GBSの病態は, ウイルスや細菌感染などが契機 となって引き起こされる自己免疫性疾患と考え られている. 血清中に各種の抗糖脂質抗体が出 現することが報告されており，何らかの感染因 子が免疫系を刺激し，抗体産生を促しているの ではないかと推察されている.ガングリオシド をはじめとする糖脂質は末梢神経の髄鞘を構成 しており，一部の例では抗糖脂質抗体が，標的 となる抗原部位に特異的に結合することによっ て，末梢神経障害を引き起こしているものと考 えられている。

GBSは世界中のあらゆる地域で発症し，人口 10 万人あたりの年間発生率は 0.6〜 1.9 人前後と
される.本邦の年間発生率は 1998 年の厚生省免 疫性神経疾患調查研究班の全国調查では人口 10 万人あたり 1.15 人であった. 平均発症年齢は 39 荿で, 男女比は $3: 2$ とやや男性に多く認められ た.GBSの約 7 割に先行感染症状が認められ, 上 気道炎症状, 次いで胃晹症状が多い. 先行感染 の主要な病原体はCampylobacter jejuni, サイトメ ガロウイルス, Epstein-Barrウイルス, Mycoplasma pneumoniaeである.

RCTで有効性が確立されている治療法は単純 血槳交換 (plasma exchange:PE) および免疫グ ロブリン静注療法 (intravenous immunoglobulin:IVIg) である.PEおよびTVIgは同等の有効 性を示すことが明らかになっている。しかし， 現時点ではPEとIVIgのいずれを第一選択とすべ きかという点に対するエビデンスはない，その ため, それぞれの治療法の長所, 短所とともに, 患者側の要因（性，年齢，基礎疾患，合併症な ど）を考慮して，患者に十分なインフォームド コンセントを得て, 治療法を選択する必要があ る.

IVIgはとト免疫グロブリン $400 \mathrm{mg} / \mathrm{kg} /$ 日を 4〜 6 時間かけてゆっくり点滴静注し,これを 5 日間, 連日投与する方法が行われる.PEは発症後 7 日 以内のできるだけ早期に治療を開始することが 重要であり，予後を決定するとされている，ま た, PEの至適回数については, 比較的軽症な 5 $\mathrm{m}$ 以上歩ける場合には 2 回, $5 \mathrm{~m}$ 以上歩けない中 等症以上には合計 4 回が至適であることが欧米 の大規模試験で示されている.PEとIVIgの有効 性には有意差はないが，治療法の簡便性や上記 に述べたような幅広い適応があることから,IVIg が治療の第一選択とされることが多い.

本邦で高頻度に選択される二重膜滤過血獎交 換 (double-filtration plasmapheresis : DFPP), 免疫吸着 (immunoadsorption plasmapheresis : IAPP) はエビデンスを踏まえた治療法としては 確立していないが，PEと同等の有効性を示唆す る少数例での報告はある. 副腎皮質ステロイド 
は，RCTにより経口，静注療法のいずれも有効 性は否定されており，単独での使用は行うべき ではない。

\section{2) CIDP}

CIDPは慢性進行性あるいは再発性に末梢神経 の散在性脱䯣が生じ，筋力低下あるいは感覚障 害を示す免疫性神経疾患である.1975 年にDyck らによる臨床病理学的検討から,最終的にchronic inflammatory demyelinating polyradiculoneuropathy (CIDP) と命名され, 今日に至っている.

小児から高齢者まで幅広く発症し，男女比で は 1.3〜3.3:1で男性優位である. 有病率は 10 万人あたり 1〜2.2人と報告されている. CIDP 患者の $13 \%$ は日常生活で何らかの介助を必要と し,54\%は治療を継続している.このようにCIDP は長期間にわたり治療を継続する必要性が高い ため, 治療法の選択にはその有効性のみならず, 長期投与に上る副作用，医療コストの側面にも 留意する必要がある。

CIDPの基本的な臨床症状は対称性の多発根神 経炎あるいは多発神経炎であり,GBSとは異なり， 再発や階段状の悪化または進行性の経過をとる. 緩徐進行性であり, 症状のピークが初発上り 8 週以降に見られる点がGBSの定義との相違であ る.典型的な臨床症状としては，近位筋・遠位 筋ともに見られる対称性の筋力低下，感覚低下 および異常感覚である。下肢の脱力のため歩行 障害を来たし，深部反射は全般性に低下・消失 する. 高度の深部感覚障害のため失調症状を伴 うこともある. 異常感覚はしばしば見られるが, 疼痛の頻度は高くない。脳神経障害は 2 - $32 \%$ に見られ, 外眼筋麻瘏, 顔面神経麻疰, 球麻疩 などがある.うっ血乳頭は $7 \%$ で見られる.GBS と同様，髄液蛋白はしばしば上昇する，易疲労 性は機能障害の要因として最も多い症状の一つ である.その他に振戦もしばしば見られる.CIDP の発現機序に関しては不明な点が多いが, 抗 myelin-associated glycoprotein (MAG) 抗体や 抗sulphated glucuronyl paragloboside (SGPG) 抗
体が陽性となるニューロパチーは治療抵抗性を 示すものが多く,一方, 抗GD1b抗体は神経細胞 体への障害により特発性慢性失調性ニューロパ チーを呈する。このように糖鎖抗原に対する抗 体により異なる臨床病理像を呈することがわかっ てきている.

現在, CIDPの治療法として, RCTにより有効 性が確立され，エビデンスが強いとされている ものは(1)副腎皮質ステロイド, (2) IVIg, (3)血液 浄化療法の 3 療法である.これらはいずれも本 邦において保険承認されており, 初回治療法と して一般的になっている. 治療の際, 問題にな るのは，第一選択としてどのような治療法を用 いるかという点である。

副腎皮質ステロイド，血液浄化療法, IVIg いずれの治療法に対しても反応しない，いわゆ る無効例がみられる.この無効例がCIDPの中で どのくらい占めるかについての検討はないが, これらの症例は難治性あるいは治療抵抗性CIDP と呼ばれる.難治性CIDPに対してはまず免疫抑 制剂を投与する.いくつかの免疫抑制剤がCIDP に対し用いられているが, シクロスポリンに対 する臨床試験が最も多く, 次いで, サイクロフォ スファミドが用いられる，インターフェロンは 海外ではRCTが行われており，インターフェロ ン $\alpha$ 有効性は免疫抑制剂より強いが, 本邦では 一般的でなく, 症例報告がみられるのみである。 今後, 難治性/治療抵抗性CIDPに対するインター フェロンの本邦での臨床試験が望まれる。

\section{参考文献}

CMT

1) Hattori $N$, et al: Demyelinating and axonal features of Charcot-Marie-Tooth disease with mutations of myelinrelated proteins (PMP22, MPZ and Cx32) : a clinicopathological study of 205 Japanese patients. Brain 126 : 134$151,2003$.

2) Zhao C, et al: Charcot-Marie-Tooth disease type $2 \mathrm{~A}$ caused by mutation in a microtubule motor KIF1Bbeta. Cell 105: 587-597, 2001.

3) Lupski JR, et al:DNA duplication associated with 
Charcot-Marie-Tooth disease type 1a. Cell 66:219-232, 1991.

4) Hayasaka $K$, et al : Mutation of the myelin $P 0$ gene in Charcot-Marie-Tooth neuropathy type IB. Hum Mol Genet 2 : 1369-1372, 1993.

\section{FAP}

1) Koike $\mathrm{H}$, et al : Type I(transthyretin Met30) familial amyloid polyneuropathy in Japan : early-vs late-onset form. Arch Neurol 59 : 1771-1776, 2002.

2) Ikeda $\mathrm{S}$, et al : Familial transthyretin-type amyloid polyneuropathy in Japan : clinical and genetic heterogeneity. Neurology 58: 1001-1007, 2002.

3) Takei $Y$, et al : Partial-liver transplantation to treat familial amyloid polyneuropathy : follow-up of 11 patients. Ann Intern Med 131 : 592-595, 1999.

4) Ando $Y$, et al : Liver transplantation in Japanese patients with familial amyloidotic polyneuropathy. Lancet 350 : 593-594, 1997.

\section{GBS}

1) Haupt WF. et al: Apheresis and selective adsorption plus immunoglobulin treatment in Guillain-Barré syndrome. Ther Apher $4: 198-200,2000$.

2) French Cooperative Group on plasma exchange in Guillain-Barré syndrome: Appropriate number of plas- ma exchanges in Guillain-Barré syndrome. Ann Neurol 41 : 298-306, 1997.

3) Plasma Exchange/Sandoglobulin Guillain-Barré Syndrome Trial Group : Randomized trial of plasma exchange, intravenous immunoglobulin, and combined treatments in Guillain-Barré syndrome. Lancet $349: 225-230,1997$.

4) Guillain-Barré Syndrome Steroid Trial Group:Double blind trail of intravenous methylprednisolone in GuillainBarré syndrome. Lancet $341: 586-590,1993$.

CIDP

1) Mendell JR, et al : Randomized controlled trial of IVIg in chronic inflammatory demyelinating polyradiculoneuropathy. Neurology $56: 445-449,2001$.

2) Gorson $\mathrm{KC}$, et al:Improvement following interferonalpha $2 \mathrm{~A}$ in chronic inflammatory demyelinating polyneuropathy. Neurology $48: 777-780,1997$.

3) Hahn AF, et al : Plasma-exchange therapy in chronic inflammatory demyelinating polyneuropathy. A doubleblind, sham-controlled, cross-over study. Brain 119:10551066, 1996

4) Hahn AF, et al : Intravenous immunoglobulin treatment in chronic inflammatory demyelinating polyradiculoneuropathy : a double-blind, placebo-controlled, cross-over study. Brain 119: 1067-1077, 1996. 